\title{
歴史的石積み橋脚の耐震安定性に関する一考察
}

\section{Study on a Seismic Stability of Historical Stone Piers}

依田 照彦** 志賀 弘明*** 小玉乃理子**** 小宮一仁****

\section{By Teruhiko YODA**, Hiroaki SHIGA***, Noriko KODAMA*** and Kazuhito KOMIYA****}

\begin{abstract}
わが国における石積み構造は、その文化財的価值だけでなく、伝統的な工法の優秀さがこれまで数多 く指摘されてきた。しかしながら、石積み橋脚に関する技術的あるいは力学的面からの検討は比較的 少ない。本論文では、石積み橋脚の耐震安定性を力学的な面から検討し、歴史的に洒值があるとされ ている空石積み橋脚の耐震安定性を考察することを主な目的としている。汎用有限要素法を用いた 2 次元動的㐫答解析により、周辺地盤を含む空石積み橋脚の耐震安定性について検討した結果、空石積 み橋脚は、基礎地盤の影響を受け、せん断破壊しやすいことが分かった。
\end{abstract}

\section{1。まえがき}

1995 年 1 月 17 日、神戸の街が大きな地震災害に見舞 われたことは今も記憶に新しい。この地震では、地震動 により多くの構造物が破壞もしくは損傷し、それに伴い 多くの人的および経済的被害が報告された。日本に数多 く存在する文化財も、未来に残すべき構造物であり、地 震などによる不可避の災害に対して被害を最小限にくい 此る必要があることは言うまでもない。

本論文では、文化財としての価值が高い土木構造物の うち、主に河川構造物として水理学的観点から考察がな されてきた、歷史的な空石積み橋脚を、その耐震安定性 に着目して、検討を行うことを目的とする。酎震安定性 の観点からすれば、石積み構造を採用する場合、空積み よりも練積みの方が好ましいことは明らかである。江戸 城の石垣でさえ、修築を施された石垣には、耐震対策と して石垣の表面から $15 \mathrm{~cm}$ の間をモルタルあるいはト口 が出ないようにした練積みとし、裹込め下方から 3 分の 1 はコンクリートとし上方 3 分の 2 は在来の割栗石を使 用していたとのことである1。

ここでは、空石積み橋脚の酎震安定性を検討する手始 めとして、空石積み橋脚と城郭の石垣との構造的な相違 を明確にした上で、従来の石垣構造の研究成果がそのま ま適用できないことを示し、空石積み橋脚と地盤を 2 次 元的にモデル化して、土質や地盤に関するデー夕を用い て、空石積み橋脚の耐震安定性を検討する。

\footnotetext{
*keyword:石積み、橋脚、耐震安定性

**フェロー 工博 早稲田大学教授理工学部土木工学科

(广169-8555 東京都新宿区大久保 3-4-1)

***学生会員 工修 早稲田大学大学院理工学研究科

(广169-8555 東京都新宿区大久保 3-4-1)

****正会員 工博 千葉工業大学助教授 土木工学科

（个275-0016 千葉県習志野市津田沼 2-17-1）
}

今回の検討結果が石材加工の形状・積み方・石積みの 補強方法などを検討する際の参考資料となることを願っ ている。

\section{2. 奶象とする空石積み橋脚}

石積みの一般的な形式は、文献 2）によれば、用いる 石を中心に分類すると、自然石を用いた野石積と一定の 大きさに加工した石を用いた切石積に分けられ、積み方 に注目すると、いろいろな形の石を不規則に積み重ねた 乱積み・乱層積みと、石をほぼ規則的に積み重齐大整層積 みに分けられる。

一方、城郭の石垣では、野面穦み、打込みはぎ、切込 みはぎ、算木積などの積み方があり、石積み構造の安定 性に刘して多くの研究が見られる ${ }^{3) ~ 6) 。 ~}$

ここでは、耐震安定性について石坦との差異を明確に する目的から、図一1 に示すような架空の石積み橋脚を 検討の対象とした ${ }^{7) 、 8) 。 ~}$

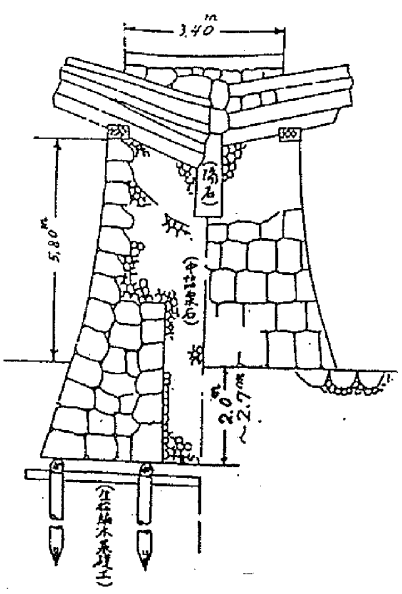

図一1 空石積み橋脚（実在しない橋脚） 


\section{3. 空石積み橋脚の耐震安定性の検討}

\section{(1)検討の概要}

震度法や保有水平陑力法では空石積み橋脚の耐震安定 性を把握することは困難であるので、ここでは動的解析 による耐震安定性の確認に主眼を置くこととする。すな わち、空石積み橋脚が受けるかも知れない地震としては 最も厳しい大規模な直下型地震が発生することを想定し て、兵庫県南部地震の地震波形を用いて動的解析を実施 し、地震時にお打る空石積み橋脚の耐震安定性を検討卞 る。具体的には、山口罧岩国市を流れる䤼川の 1998 年 時点での土質および地盤条件のデータ9）をもとに、沉用 有限要素法 (ABAQUS) を用いて、空石積み形式の橋 脚の耐震安定性評伍を行う。

\section{(2)検討の方針}

モデル化としては、空石䅧み橋脚の 3 次元的な効果を 考慮することができない 2 次元解析モデルを採用した。 これは、動的挙動のシミュレーションとしての不完全性 よりも、動的解析法としての信賴性に重点を置き、沉用 有限要素法プログラム (ABAQUS) を用いて、地盤の 塑性化を考慮した非線形時刻歴応答解析を実施すること を意図したためである。したがって、解析モデルには、 後に述べる制約条件が付与されることになる。

計算の簡略化のため、橋脚上の上部構造の影響は無視 している。通常、石積み構造には、基礎工が存在するが、 今回の解析では、松杭程度の基礎工を想定して、直接基 礎として解析を行っだ。さらに、石積み橋脚を持つ実際 の橋梁では、橋脚が隣接してあるはずであるが、ここで は隣接橋脚同士の相互作用を無視するため、単独の石積 み橋脚を扱っている。

\section{(3)地質条件}

錦川の地質は、全体的に砂や砂などの粗粒な未固結堆 積物からなっており、現地調查によって得られた地層の 土質状況は表一 1 の通りである ${ }^{9)}$ 。表一1中の記号につ いては、図一3と対応させてある。

\section{表-1 地層一覧}

\begin{tabular}{|c|c|c|}
\hline 土質名 & 記号 & 土質状況 \\
\hline 敷石、唅石 & B & $\begin{array}{l}\phi 20 \sim 80 \mathrm{~mm} \text { の䃯、玉石主体。 } \\
\text { 最大礫径 } \phi 400 \mathrm{~mm}_{\text {。 }} \text { 所々砂が卓 } \\
\text { 越する。 }\end{array}$ \\
\hline $\begin{array}{l}\text { 沖積玉石混り砂 } \\
\text { 碟 }\end{array}$ & $\mathrm{Ag}$ & $\begin{array}{l}\phi 10 \sim 20 \mathrm{~cm} \text { の玉石混入。 } \phi 2 \sim \\
70 \mathrm{~mm} \text { の亜円礫混入。マトリクス } \\
\text { は粗砂主体。 }\end{array}$ \\
\hline 沖積磜混り砂 & As2 & \begin{tabular}{|l|} 
砂は粗砂主体。 $\phi 10 〜 30 \mathrm{~mm}$ の \\
亜円磷を混入する。 \\
\end{tabular} \\
\hline 洪積砂礫 & Dg & $\begin{array}{l}\phi 2 \sim 50 \mathrm{~mm} \text { の円〜带角碟混入。 } \\
\text { マトリクスは細〜粗砂主体。 }\end{array}$ \\
\hline
\end{tabular}

\section{(4) 2 次元有限要素法による空石積み橋脚の安定照查}

a)解析プログラム

解析プログラムとしては、汎用コードのA B A QU S を利用した ${ }^{10)}$ 。これは、前提条件が正しければ、解析結 果の信頼性にばらつきがないことを保証したいがためで ある。

\section{b)入力地震動}

基本的には道路橋示方書 ${ }^{11}$ に準じるものとし、内陸 型直下地震(兵庫県南部地震クラス)を用いた。地震波と しては、実際に神戸海洋気象台で観測された地震波と同 じ波が空石積み橋脚の直下に入力することはないと思わ れるが、地震基盤は耐震設計上 I 種地盤を想定している ので、同種地盤の神戸海洋気象台の記録波形(南北方向) を使用した。な拉、地震波の上下成分については影響が 少ないものと考光、無視した。神戸海洋気象台で記録さ れた具体的な時刻歷加速度を図一 2 に示す。この地震波 を、直接解析モデルの基盤に入力しているので、石積み 橋脚兮受ける地震力としては最大級のものを想定してい ることになる。

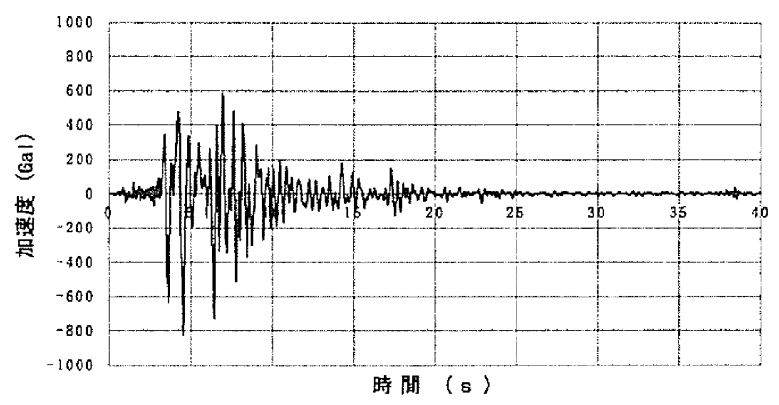

図-2 神戸海洋気象台・時刻歷加速度記録(南北方向)

c)解析モデル

解析に用いた空石積み橋脚のモデルを図一 3 に示す。 解析に用いた要素は 4 節点平面ひずみ要素 C P E 4 R (線形・低减積分・アワーグラス制御)である。また、破 壊基隻は Mohr-Coulomb（モール・クーロン)の弾塑性 破壊基準を考慮している。材料パラメータは表一 2 に示 す通りである。この材料パラメータは山口県岩国市を流 れる錦川における值”をもとに設定しているが、解析対 象地盤はN 值が概ね 10〜20 以上の締まった密な砂碩地 盤であることから、本解析モデルでは液状化は生じない ものと仮定した。また、地盤の透水性が良好であること から、過剩間隙水圧の消散は瞬時に完了するものとして、 排水解析を行った。このため、有効内部摩擦角 40 度、 粘着力 $\mathrm{C}=0$ 、ポアソン比（約 0.38）を土質条件の基本 とすることとした。

しかしながら、沉用コードを用いたため、自重解析を 実施するにあたって、地盤の粘着力をゼロとすることが できず、解析の円滑化を図るため地盤の粘着力として比 
較的小さな值 $2 \mathrm{tf} / \mathrm{m}^{2}$ を利用することとした。さらに、ポ アソン比については、有効内部摩擦角から算定する方法 も提案されているが ${ }^{12)} 、$ 解析結果に及ぼす影響は小さい ものとして地盤のポアソン比を 0.4 に統一した。なお、 解析は静的自重解析とそれをふまえた動的応答解析の 2 つのステップに分けた。加速度は図ー3に示すように、 地盤モデルの兩端および下端の全節点に同時に入力した。 また、神戸海洋気象台記録波の加速度は 0.01 秒ごとに 10 秒まで入力した。

d)動的応答解析結果

動的㐫答解析結果を図-4〜8に示す。まず、図一 4 を 見ると、地震波の入力点の水平変位に比心゙て、石積み橋 脚天端の最大応答変位が 3 倍強となっており、図一6の 変形図から判断しても地盤の変形が大きいことが分かる。 また、図一5の加速度応答の時刻歷を見ても、加速度入 力点の 3 倍強の加速度が橋脚の天端で生じている。

本解析では石積みの石同士のずれや、地盤と石積みと の閒の滑り・剥離を若虑していないので、図一 5 や図一 6 の加速度応答、変形図のみならず、自重解析にもその
影響が出ている。すなわち、図一7に見られるように、 空石積み橋脚の下端近傍に大きなせん断応力が発生して いる。図中では、カラーの図を複写したため、明るい方 のせん断応力分布が見えないが、せん断応力分布はほぼ 対称になっている。

動的応答解析の結果によれば、まず地盤がせん断破壊 し、その後空石積み橋脚が大きく変位している。前述し たように、本解析では石同士のずれや石の落下などは考 慮していないので、図からだけでは実際の動的破壊現象 を想像することは難しい。しかしながら、空石積多橋脚 が崩壊することを示唆する計算結果としては、図一8に 見られるように橋脚内部の中詰土がせん断破壊している ことが挙げられる。橋脚内部の中詰土が破壊すれば、空 石積みはその形状を保持できないので崩壊する可能性が 高い。

以上の解析結果を総合すると、空石積み橋脚の耐震安 定性については、兵庫県南部地震規模の内陸直下型大地 震が発生したときには、中詰士にせん断破壊による損傷 が生じ、空石積みが変形し、場合によっては使用できな い状態で橋脚が傾くことが推定される(図一 6 )。

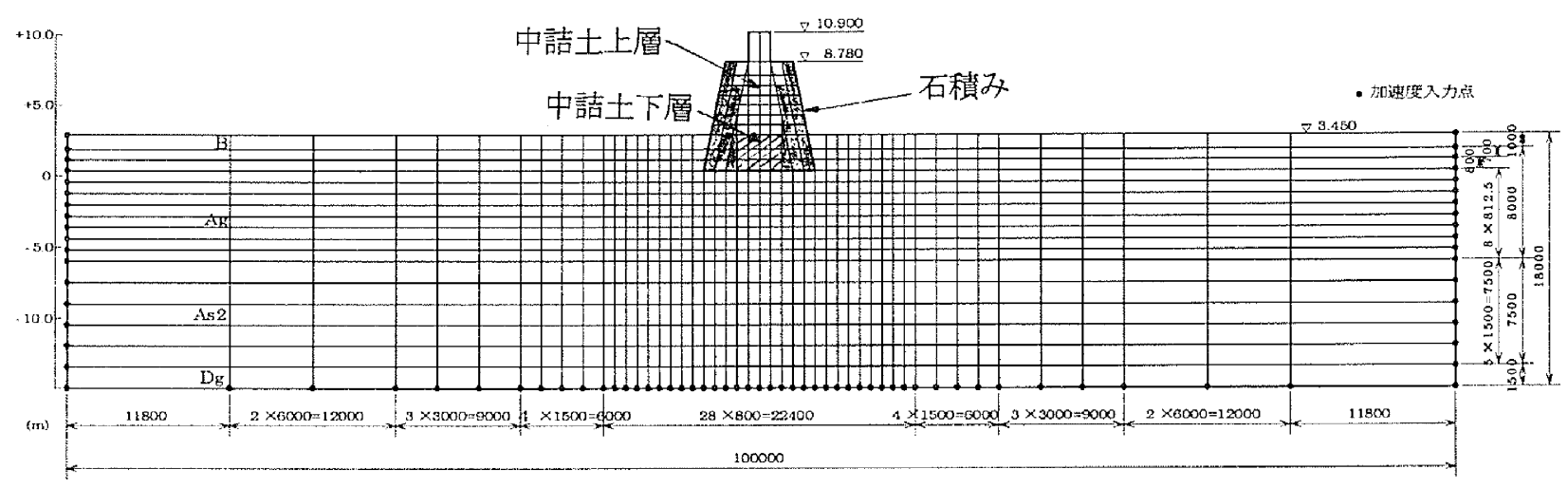

図一3 解析モデル

表一 2 材料パラメータ

\begin{tabular}{|c|c|c|c|c|c|c|}
\hline \multicolumn{2}{|l|}{ 土質 } & $\begin{array}{l}\text { 粘着力 } \\
\mathrm{tf} / \mathrm{m}^{2}\end{array}$ & $\begin{array}{l}\text { 摩擦角 } \\
\text { deg }\end{array}$ & $\begin{array}{l}\text { 単位体積重量 } \\
\mathrm{tf} / \mathrm{m}^{3}\end{array}$ & $\begin{array}{l}\text { ヤング率 } \\
\mathrm{tf} / \mathrm{m}^{2}\end{array}$ & ポアソン比 \\
\hline \multirow{4}{*}{ 地盤 } & $\mathrm{Dg}$ & 2 & 40 & 2.1 & $3.5 \times 10^{3}$ & 0.40 \\
\hline & As2 & 2 & 35 & 1.9 & $1.8 \times 10^{3}$ & 0.40 \\
\hline & $\mathrm{Ag}$ & 2 & 30 & 2.0 & $8.0 \times 10^{2}$ & 0.40 \\
\hline & $\mathrm{B}$ & 2 & 40 & 2.0 & $3.5 \times 10^{3}$ & 0.40 \\
\hline \multicolumn{2}{|c|}{ 中詰土上層 } & 6 & 40 & 2.2 & $3.5 \times 10^{3}$ & 0.40 \\
\hline \multicolumn{2}{|c|}{ 中詰土下層 } & 9 & 40 & 2.2 & $3.5 \times 10^{3}$ & 0.40 \\
\hline \multicolumn{2}{|c|}{ 石積み } & 100 & 40 & 2.5 & $5.0 \times 10^{5}$ & 0.20 \\
\hline
\end{tabular}




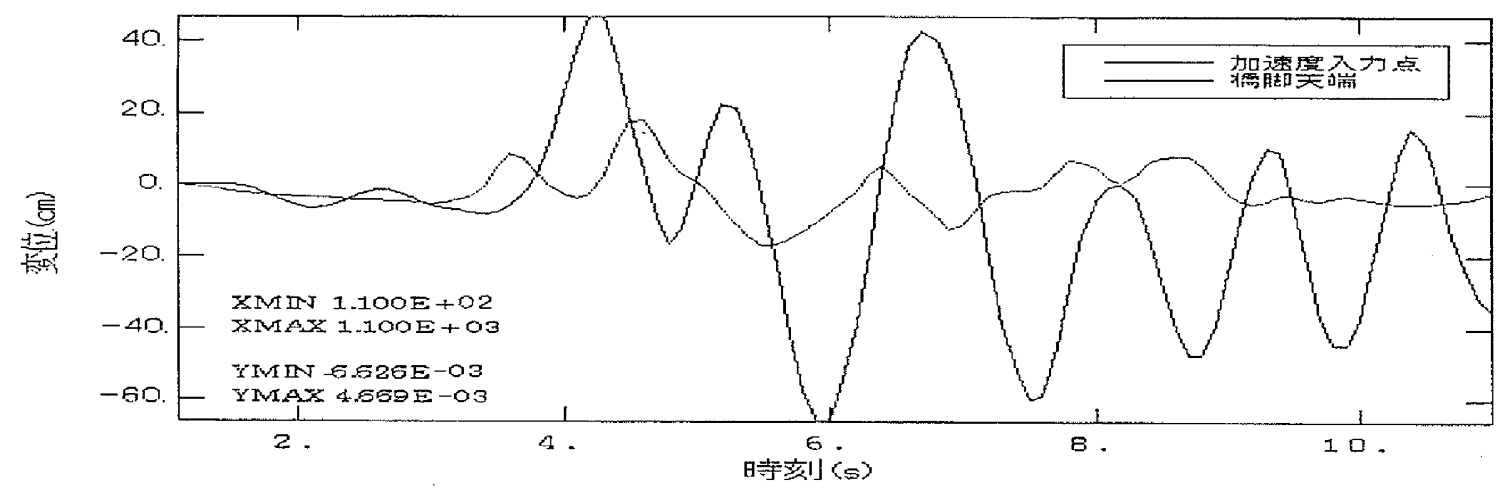

図一4 時刻歷変位応答[水平方向]

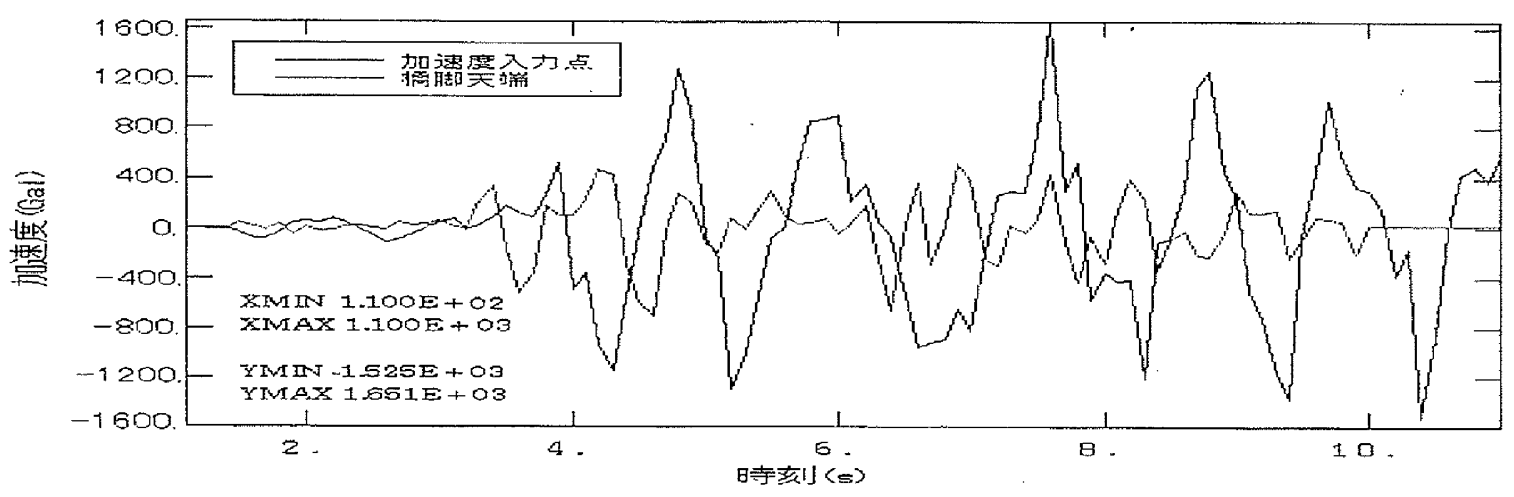

図一5 時刻歴加速度応答[水平方向]

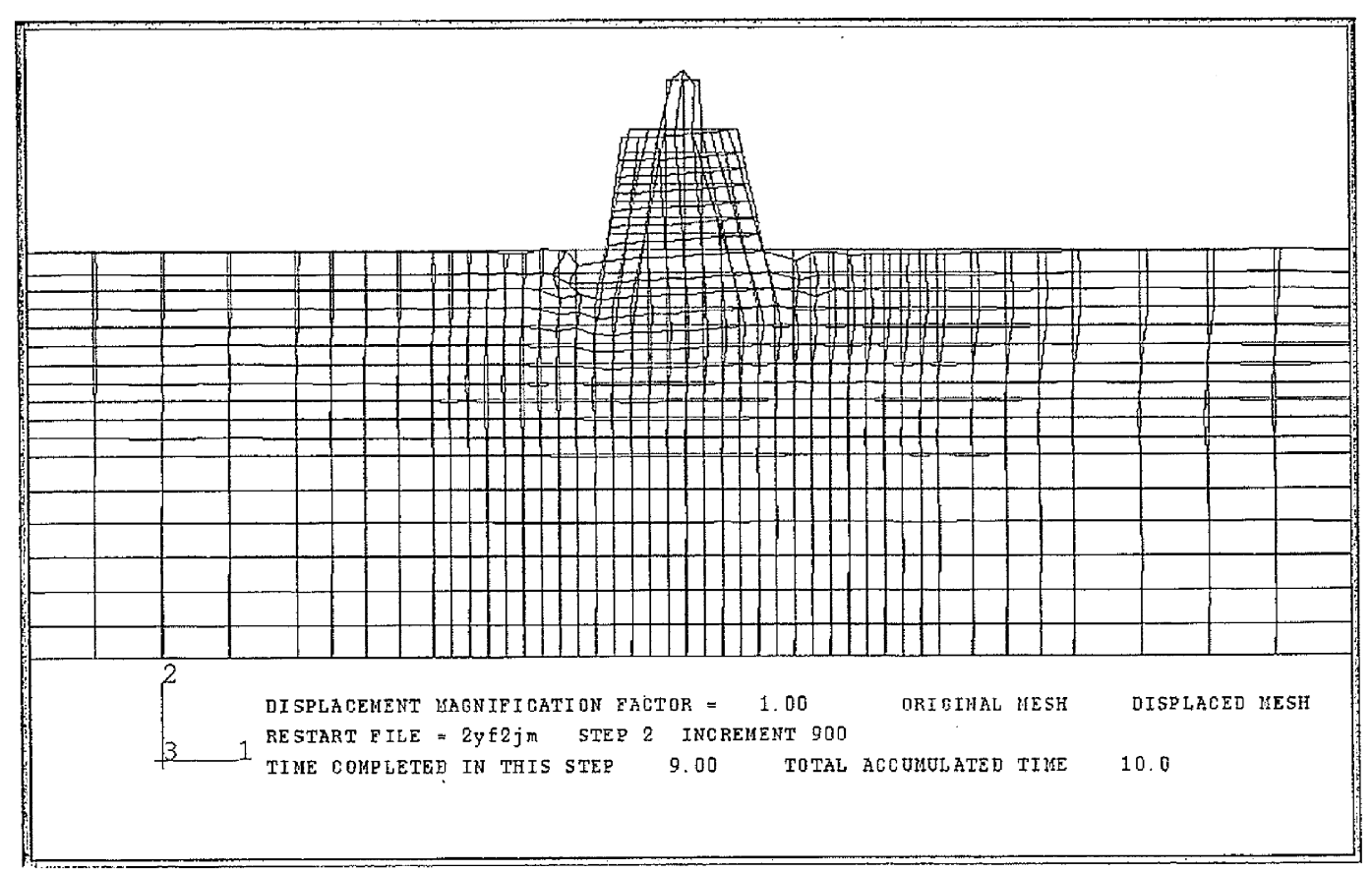

図一6 変形図 $(\mathrm{t}=9 \mathrm{~s})$ 


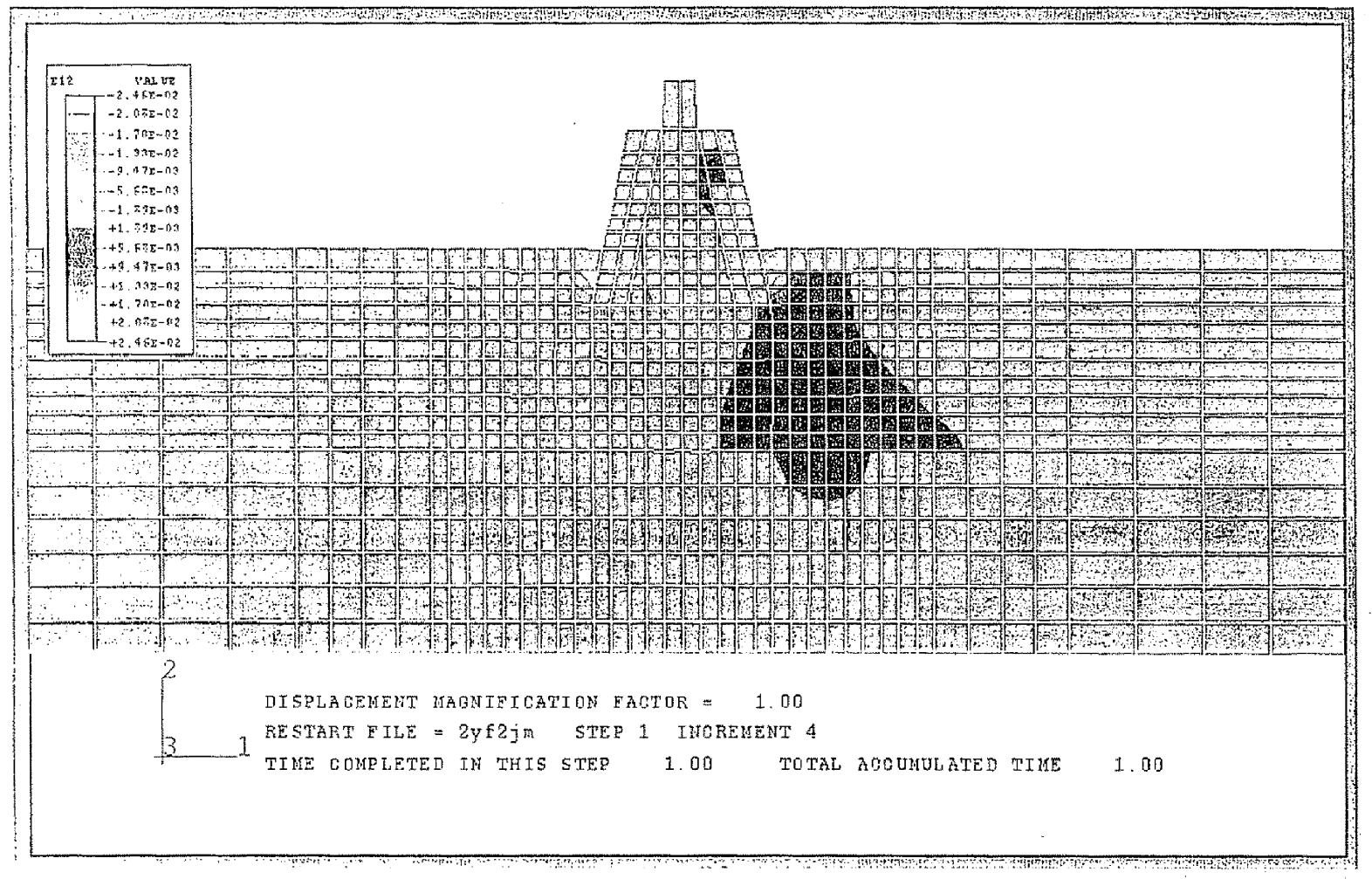

\section{図一7 全せん断ひずみ図（自重解析）}

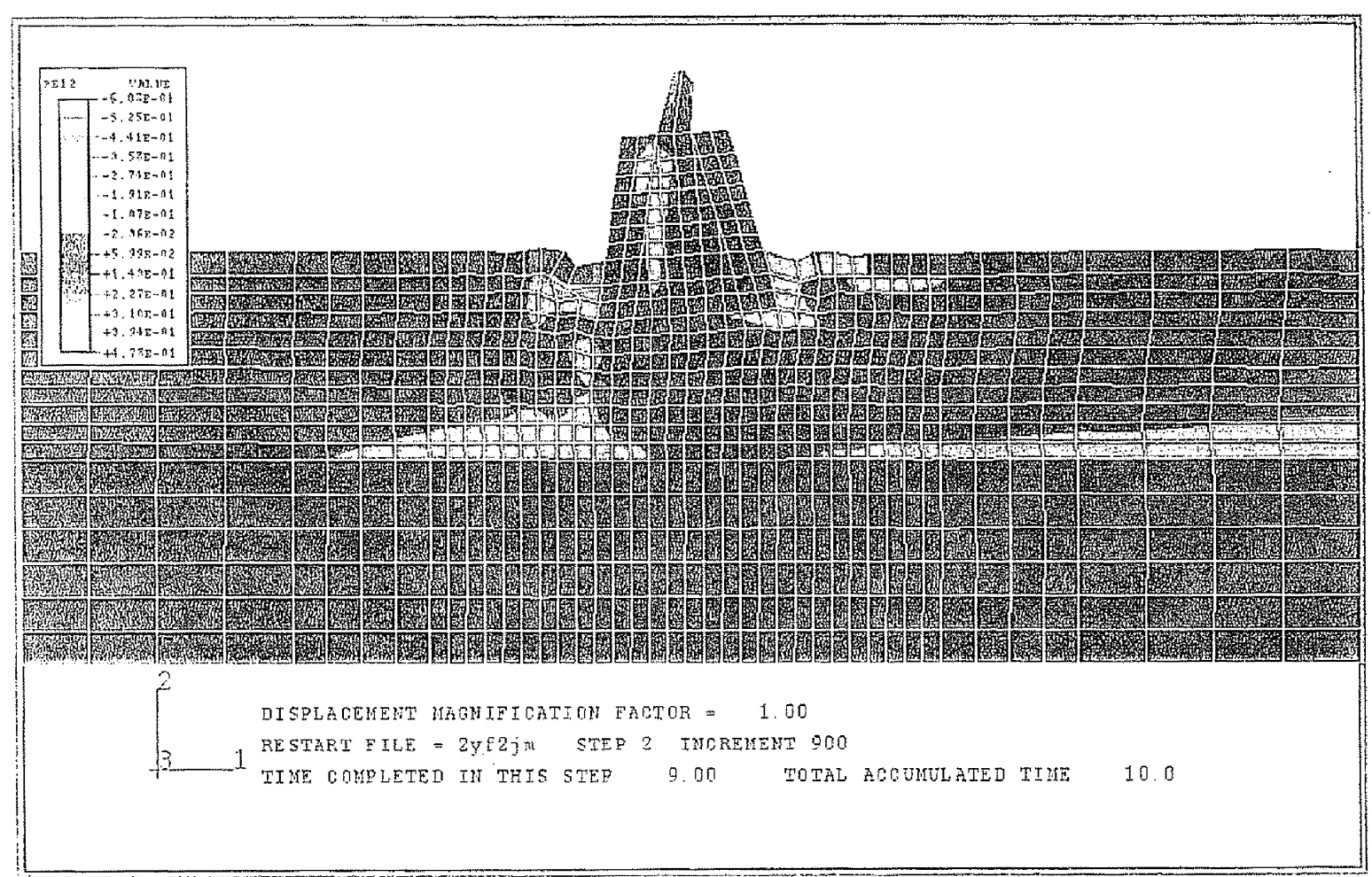

図一8 塑性さん断ひずみ図（t=9s） 


\section{4.あとがき}

ここでは、空石積み橋脚の耐震安定性に関する比較検 討を行ったが、有限要素法を用いた動的解析の結果から 判断すると、地震時の石積み橋脚の動的挙動は土質工学 的な要因で決定され、石積みの形式の違いはそれ程大き くないと思われる。特に、城郭の石積みのような地盤の 滑りは起こらず、石積み橋脚のせん断破壊が先行する点 に特徽があり、この点が城の石垣と大きく違う点である。 つまり、空石櫝み橋脚では、城郭の石垣のように石の奥 行きを梁くできず、耐震安定性を図る上での自由度はそ れ程多くないと考えられる。たとえば、文献 3）に見ら れるような石垣の「扇の勾配なな゙は石積み橋脚では難し く、全く新しい横断面形状を採用すると、水理学的な面 のみならず、景観的な面からの再考が必要となり、場合 によっては歴史的な洒值を半減させることに慗がる可能 性があると思われる。

今後は、文化財としての空石積み橋脚と、耐震安定性 の面からの空石積み橋脚の接点を探る意味で、石積み技 術の伝承とともに、経済性・景観性を含めた広い視野か らの新たな石積み形式の検討が必要になると思われる。

謝辟：本研究をまとめるにあたり、このような研究の機 会を与えていただいた岩国市錦带橋修復検討委員会専門 部会[部会長:大熊孝新鳰大学教授]と岩国市経済部商工観 光課の関倸各位に深甚なる謝意を表します。また、錦川 の地盤定数については、岩国市役所より貴重なデータを いただきました。記して感謝を申し上げます。

\section{参考文献}

1 )新谷洋二：城の石垣修築に関する雑感、建設業界、 pp.46-49、1998 年 12 月

2) 土木学会編：『土木用語大辞典』、技報堂出版、p.38、 1999 年 2 月

3 )田中邦熙・山田清臣：石積み擁壁の安定性評価法、土 木学会論文集、III-35、No.541、pp.9-20、1996 年 6 月

4)西田一彦・ 山野寿雄・ 中村博司· 久保勝保・ 玉野富雄 中川光雄 : 大坂城石垣の歴史的崩壊記録と安定に関す る考察、土木史研究、No.16、pp.601-608、1996 年 6 月

5)田中邦熙・新谷洋二・山田清臣 : 石垣断面解析に FEM を適用するための閒詰部の考え方と解析事例、士木史 研究、No.18、pp.491-501、1998 年5 月

6)田中邦熙·新谷洋二・山田清臣 : 石垣の安定性に関す る各種の判定手法の比較検討、土木史研究、No.18、 pp.139-152、1998 年 5 月

7) 土木学会:『大正 12 年関東大地震震害調查報告書 (第 三巻) 』、pp.443-502、1925 年 12 月

8)永田新之允：『錦带橋史及、岩国観光男会、巻頭写真版 目次 付図表、1953 年 12 月

9)岩国市役所: 岩国錦带橋修復検討委員会専門部会資料、
錦帯橋下部工健全度調查結果、1998 年 11 月

1 0) ABAQUS/Standard: [User's Manual I,II 』 日本語版 Version 5.4, Hibbit, Karlsson, Sorensen, Inc., 1997

11）日本道路協会：『道路橋示方書・同解説 V 耐震設 計編』, 丸善, 1996 年 12 月

12 ）飯塚敦・太田秀樹・良峰透：弹塑性有限要素法に おける入力パラメータの決定法、第 20 回土質工 学研究発表会講演集、pp.973-974、1985 年 